\title{
An Enduring Path for National Unity and Human Rights Protection in Ethiopia: A Case for Human Dignity Centered Constitutional Design and Interpretation
}

Tsega Andualem Gelaye *

\begin{abstract}
Ensuring National Unity and upholding Human Rights have always been a big challenge in Ethiopia, since the establishment of the modern Ethiopian state. These problems are still troubling the country, long after the adoption of the present Federal Democratic Republic of Ethiopia (FDRE) Constitution, which is claimed to have addressed them once and for all. This article seeks to revisit the historical underpinnings of the FDRE Constitution and its ethnic-centered design, in relation to its actual capacity to achieve national unity and adequate protection of human rights. The article demonstrates how human dignity centered constitutional design and interpretation could advance both national unity and adequate protection of rights. It argues that the historical foundation of the FDRE Constitution and the design that came out of it is backward looking, exclusionary and inadequate to address both challenges for a number of reasons. As a possible alternative, it proposes a human dignity centered rereading of history, constitutional design and interpretation. Since Ethiopia is in a process of reform in various spheres, the issues raised and discussed in the article deserve serious attention as they are essential to move forward.
\end{abstract}

\section{Key terms:}

Ethnic federalism $\cdot$ National unity $\cdot$ Human rights $\cdot$ Human dignity $\cdot$

Constitutional design $\cdot$ Ethiopia

DOI http://dx.doi.org/10.4314/mlr.v15i1.1

This article is licensed under a Creative Commons Attribution-

NonCommercial-NoDerivs (CC BY-NC-ND)

Received: 31 March 2021

Accepted: 11 August 2021

* Tsega Andualem Gelaye: LL.B, LL.M in Human Rights Law (Addis Ababa University), LL.M in Comparative Constitutional Law (Central European University), (SJD in Comparative Constitutional Law, Central European University), Assistant Professor, Ethiopian Civil Service University, School of Law and Federalism.

Email: tsega.andualem@gmail.com ORCID: https://orcid.org/0000-0002-1635-6349

The initial version of the themes in this article was presented in a conference organized by AAU Law School in June 2018. The author would like to thank colleagues and anonymous reviewers who provided him with valuable and constructive feedback. 
Suggested citation:

Tsega Andualem Gelaye (2021), 'An Enduring Path for National Unity and Human Rights Protection in Ethiopia: A Case for Human Dignity Centered Constitutional Design and Interpretation', 15(1) Mizan Law Review: 1-40

\section{Introduction}

The adoption of a new constitution is usually associated with the beginning of a new dawn and chapter in the history of a nation. However, this supposition is not always true. It is only in those nations which were able to identify the root cause of the illness in their past and prescribed the right medication for it that a new chapter is likely to start with the coming of a new constitution. Ethiopia was not lucky in that regard. This article contends that although national unity and lack of respect for fundamental rights were identified among the core problems of Ethiopia, they were not addressed properly in the design of the present constitution, mainly due to a simplistic and backward looking reading of the Ethiopian past by the political actors who dominated the constitution making process. To remedy this problem, I argue that a human dignity centered reading of history, constitutional design and interpretation can have a great potential to achieve National Unity and promote the protection of Human Rights.

The article is based on the premise that Ethiopia is one sovereign statenation. This paradigm is different from related conceptions of 'nation-states' and 'pure multinational states'. At the core of the nation-state conception is the idea that there should be one homogenous culture, language and identity within a state. ${ }^{1}$ This framework is inadequate for Ethiopia because it is a home of multiple and diverse ethnic communities with their own language, culture and traditions. The idea of 'pure multinational state' also seems to be problematic for Ethiopia because of its inability to ensure the unity and integrity of the country. This conception gives too much power for national groups within the state and is more like a confederation of nation-states. ${ }^{2}$ Such arrangement does not give much attention to the common values and opens the door for disintegration of the state since the prime attachment of the inhabitants is to their respective ethnic community rather than the state.

In contrast to the two paradigms (i.e., the nation-state and pure multinational state), the idea of state-nation seeks to balance between

\footnotetext{
${ }^{1}$ Alfred Stephan et al (2011), Crafting State-Nation India and other, Multinational Democracies, (The Johns Hopkins University Press) 2-8.

${ }^{2} \mathrm{Id}$. at $11-12$.
} 
diversity and unity. As such, it recognizes the importance of accommodating diversity be it ethnic, religious or cultural within a state. It seeks to strengthen the unity of the people as well as the integrity of the state. It also accepts that multiple identities could coexist within a state in a complimentary manner. ${ }^{3}$ In other words, nationality and citizenship could supplement each other; i.e., membership of a certain national group does not affect loyalty to the state as a citizen. It is based on this assumption that arguments in this article are made concerning the need to maintain national unity, territorial integrity and make citizenship the primary identity marker for distributing rights and duties. If one does not accept the state-nation status of Ethiopia for whatever reason and regards it as a loose association or confederation of independent/autonomous ethnic communities, the conclusion he/she would reach on such matters would obviously be different.

The other core/crucial concept embodied in the article is the notion of national unity. Different people may perceive the idea differently. For some, it may mean the eradication/amalgamation of diversity within a state and the creation of one identity by force or other means. The idea of national unity used in this article is completely different from this conception. It rather accepts the immense importance of recognizing ethnic, cultural and religious diversity of different communities. These differences must not be however a source of conflict and disharmony among the inhabitants of the nation. Despite differences along ethnic or religious lines, citizens of a state-nation need certain core unifying/shared values that bind them together and enable them to live in cooperation, harmony, peace and move forward. Thus, the concept of national unity, in this article envisages the subtotal of core values that bind citizens of a nation together irrespective of their ethnic and religious diversity.

Identifying these unifying values that appeals to all and ensuring national unity is extremely important in Ethiopia for two main reasons. First, the Ethiopian state is constituted by forceful expansion and assimilation rather than the consent of various communities inhabiting it. Even after its establishment, the state has failed to respect basic human rights and treat all in equal manner. This has created a resentment which could be a cause for division, instability and conflict. To rectify this problem with the past history of the country, Ethiopian people need a new basis/foundation for their union which they willingly subscribe, because it attends to their needs and

${ }^{3} I d$. at 4 . 
recognizes their equal worth. Second, the presence of diverse and multiple ethnic as well as religious groups in Ethiopia is another factor that makes ensuring national unity desirable.

Considering the extent of diversity in ethnicity, language, culture and religion that prevails in Ethiopia some may argue that, there is nothing that is shared among the Ethiopian people and they could not live together as such. This however is far from the reality. To a considerable degree, the various ethnic and religious communities inhabiting Ethiopia have created shared identity (the magnitude of which can be subject to debate) as they lived together for long time and interacted in social, economic and cultural spheres. Even if one accepts the proposition that there is no shared Ethiopian identity to date for the sake of argument, it is also within the realm of possibility to create one through agreement. As such, neither uniformity in ethnic composition nor the existence of one religion is essential for establishment of a state-nation. A strong state-nation could be created out of a diverse community and individuals so long as they are committed to certain core values and are willing to live together. The case of the United States of America is a good example in this regard.

As argued in the article, regardless of differences in ethnicity and religion in Ethiopia, there is one core value that is commonly shared by all i.e. humanity, respect for human dignity or worth of a human being. This value could bring together the diverse people of Ethiopia under one umbrella as it preserves the essence of their humanity at various levels both individual and communal. It could also serve as a yardstick for balancing the right of individuals and communities within a state. Unlimited amount of right for communities be it ethnic or religious threatens individual liberties and the very existence of the state. It could also be a cause for conflict and instability. On the other hand, promoting individual rights alone while ignoring or at times suppressing collective rights is also a recipe for disaster. It is with due consideration of these facts that this article advocates for a human dignity centered constitutional design and interpretation because of its capacity to preserve the interest of individuals and communities concurrently without one destroying the other.

The article takes inspirations from the constitutions of South Africa, Germany, India and others. These jurisdictions were primarily chosen due to the central place of human dignity in their constitutional order. Some of them had also influenced the design of the FDRE constitution.

The next section introduces the idea of human dignity as philosophical, political and constitutional concept. Its core functions in major constitutional systems will also be briefly stated. The third section critically examines the 
historical underpinning of the FDRE Constitution and the design that comes out of it from the perspective of national unity and human rights protection. The fourth and fifth sections explore the potential of human dignity centered constitutional design and interpretation in addressing challenges of national unity and ensuring respect for human rights. These sections also indicate the avenues to achieve this concretely and the possible challenges. Finally, the core arguments of the article are highlighted and presented along with concluding remarks.

\section{Human Dignity as Philosophical, Political and Constitutional Concept}

\subsection{Human dignity as religious, philosophical and political concept}

The notion of human dignity first emerged in philosophical and religious discourse. ${ }^{4}$ Both philosophers and religious scholars were engaged in finding an answer to the fundamental question, what makes human beings unique and worthy of a special respect in comparison to other creatures? For theologians and other religious scholars, the uniqueness of human beings emanates from their special pattern of creation by God. For instance, Christian theologians invoke the Bible verse which says 'God created man in his own image'. ${ }^{5}$ In their view the resemblance between man and God elevates the status of human beings justifying their treatment with greater respect. A similar verse is found in the Holy Quran which states that 'man is the representative of Allah on earth'. ${ }^{6}$ This has been interpreted to demonstrate the status of human beings and their ascription with a unique value or dignity. Likewise, various traditional beliefs share similar concepts in different forms. For example, according to the traditional religious beliefs of the Igbo indigenous people of West Africa, human beings deserve a special respect and recognition because they embody the 'imprint of God or Chi'. ${ }^{7}$

\footnotetext{
${ }^{4}$ Aharon Barak (2015), Human Dignity the Constitutional Value and the Constitutional Right, (Cambridge University Press) 15-33.

${ }^{5}$ Erin Daly (2013), Dignity Rights: Courts, Constitutions, and the Worth of the Human Person (University of Pennsylvania Press) 30.

${ }^{6}$ Miklos Maroth (2014), 'Human dignity in the Islamic World' in Marcus Düwell and others (eds), The Cambridge Handbook of Human Dignity: Interdisciplinary Perspectives (Cambridge University Press) 157.

${ }^{7}$ Kehinde E. Obasola (2014), 'Ethical Perspective of Human Life in Relation to Human Rights in African Indigenous Societies' 8 International Review of Social Sciences and Humanities 29-35.
} 
Based on a different premise, philosophers also accept the idea that human beings possess a unique worth and need to be treated accordingly. The most notable philosopher in relation to the notion of human dignity is Immanuel Kant. He argued that the source of human dignity is their capacity for moral action and reason. ${ }^{8}$ In his view, human beings are capable of sophisticated thinking and acting on that basis. This feature is shared by all human beings/human race, despite possible variance of degree. They are also bestowed with the capacity to distinguish right and wrong. This unique capacity of human beings to exercise their autonomy in line with moral principles makes them stand out from other creatures. ${ }^{9}$

Kant tried to set or establish a categorical imperative regarding how human beings should be treated. He stated that 'human beings should be treated as an end in themselves not as means'. ${ }^{10}$ In other words, no human being must be assumed to exist for the sake of benefiting or pleasing others. Rather he/she has a value in himself/herself regardless of his/her use or benefit for others. This opposes the social system in slave societies where a slave owner considers the slave as his own property. For him the slave has no mission or value other than serving his master. Kant rejected such thinking of enslaving or ownership of humans by asserting that they are not the object of anything but have worth and dignity as ends in themselves.

The central feature of Kant's philosophical conception of human dignity is that it is innate or intrinsic. This could be differentiated from the understanding of human dignity as a political notion which is founded on deliberation and agreement of autonomous individuals to treat each other with respect. ${ }^{11}$ Such agreement could be expressed in the form of constitution or other laws adopted following a democratic process. Thus, for certain political theorists the source of human dignity rather arises from the voluntary agreement of individual human beings.

According to Jürgen Habermas, human dignity "performs the function of a seismograph that registers what is constitutive for a democratic legal order, namely, just those rights that the citizens of a political community must

8 Matthias Mahlmann (2012), 'Human Dignity and Autonomy on Modern Constitutional Orders' in Michel Rosenfeld and András Sajó (eds), The Oxford Handbook of Comparative Constitutional Law (Oxford University Press) 370-396.

${ }^{9}$ Ibid.

${ }^{10}$ Ibid.

${ }^{11}$ Jürgen Habermas (2010), 'The Concept of Human Dignity and The Realistic Utopia Of Human Rights', 41(4) Metaphilosophy 464, 464-480 \& Adeno Addis (2013), 'The Role Of Human Dignity in a World of Plural Values and Ethical Commitments 31(4)Netherlands Quarterly of Human Rights 403, $424 \mathrm{ff}$. 
grant themselves if they are to be able to respect one another as members of a voluntary association of free and equal persons". ${ }^{12} \mathrm{He}$ also underscores the vital link between human dignity and citizenship and considers 'democratic citizenship' as the basis for individuals' claim to be treated with respect or dignity. ${ }^{13}$ All these diverse conceptions of human dignity have left their imprints and contributed their part for the development of human dignity as a legal concept.

\subsection{Human dignity as a legal and constitutional concept}

Compared to the long history of human dignity as a religious and philosophical concept, its emergence as a legal and constitutional concept has a relatively short history. ${ }^{14}$ The landmark development in this regard occurred following the shocking incidents that took place prior to the end of the Second World War which include the tragic Holocaust against the Jews. ${ }^{15}$ The Nazi party which was holding power in Germany at that time had the ideology of making Europe Jew-free.

Initially, the plan was to deport all persons of Jewish decent to Madagascar. This was commonly known as the 'first solution' to the Jewish problem. ${ }^{16}$ However, the Nazi leaders of the time found the implementation of this solution to be cumbersome and costly in financial terms. They rather adopted another 'solution' which was keeping the Jewish population in Europe in concentration camps built in different places. This second option also did not satisfy the Nazi leaders and they adopted a 'final solution' which was extermination of all Jews in the concentration camps. ${ }^{17}$

In order to kill as many Jews as possible, the Nazi leaders ordered the construction of gas chambers. They also thought this makes their death more 'humane' and 'painless'. ${ }^{18}$ With the policy of final solution more than six million Jews were massacred. Besides the killing, the Jewish people in the concentration camps were also subjected to horrific medical experiments. ${ }^{19}$

\footnotetext{
${ }^{12}$ Ibid.

${ }^{13}$ Ibid.

${ }^{14}$ Barak, supra note 4, 49-65.

${ }^{15}$ Christopher McCrudden (2008), 'Human Dignity and Judicial Interpretation of Human Rights' 19(4) EJIL 625, 625-72

${ }^{16}$ Hannah Arendt (1963), Eichmann in Jerusalem: A Report on the Banality of Evil (Penguin Classics) 62-82 ff.

${ }^{17}$ Ibid.

${ }^{18}$ Ibid.

${ }^{19}$ The Doctors' Trial, The United States of America vs. Karl Brandt et al. US Military Tribunal Nuremberg, Judgment of 19 July 1947.
} 
During these tragic atrocities, the Nazis considered the Jews as sub-humans not deserving any respect that is owed to a human person. This was entirely incompatible with the idea that human beings possess human dignity and need to be treated with a special respect.

This shocking experience and the destruction that ensued as a result of the Second World War taught an important lesson to humanity. It also necessitated the incorporation of human dignity in the key international treaties. The transformation of human dignity from a philosophical religious and political concept to a legal concept first occurred in the international arena in the UN Charter that seeks 'to reaffirm faith in fundamental human rights, in the dignity and worth of the human person'. ${ }^{20}$ This trend of recognizing human dignity in international treaties increased in the subsequent years.

A number of international and regional human rights treaties expressly stated the importance of human dignity. For instance, the Universal Declaration on Human Rights states that 'all human beings are born free and equal in dignity and rights. They are endowed with reason and conscience and should act towards one another in a spirit of brotherhood'. ${ }^{21}$ The Declaration underscored the equality of all human beings in their human quality and the need to treat one another with respect and care. A similar reference is found in the International Covenant on Civil and Political Rights (ICCPR) and the African Charter on Human and People's Rights (ACHPR).

The preamble of the ICCPR provides 'recognition of the inherent dignity and of the equal and inalienable rights of all members of the human family is the foundation of freedom, justice and peace in the world' ${ }^{22}$ It further makes human dignity the base or foundation of human rights. The Covenant says human rights 'derive from the inherent dignity of the human person' ${ }^{23}$ Thus, the source of our human rights is the dignity we possess as human beings. The regional African human right treaty, the ACHPR for its part provides 'every individual shall have the right to the respect of the dignity inherent in a human being and to the recognition of his legal status. All forms of exploitation and degradation of man particularly slavery, slave trade, torture, cruel, inhuman or degrading punishment and treatment shall be prohibited'. ${ }^{24}$ As such, the Charter not only recognizes the special worth or

\footnotetext{
${ }^{20}$ United Nations Charter 1945, preamble.

${ }^{21}$ Universal Declaration on Human Rights 1948, art.1.

${ }^{22}$ International Covenant on Civil and Political Rights 1966, preamble.

${ }^{23}$ Ibid.

${ }^{24}$ African (Banjul) Charter on Human and Peoples' Rights (ACHPR) 1986, art.5.
} 
value of human beings but also indicates instances where the dignity of human beings is undermined. All the statements in the above-mentioned international and regional human rights treaties demonstrate the importance of human dignity as their very foundation.

The next stage in the development of human dignity as a legal concept occurred with its increasing and widespread recognition in several national constitutions. ${ }^{25}$ The pioneer in this regard is the Basic Law of the Federal Republic of Germany. After the end of the Second World War, Germany adopted a new constitutional order that is centered on Human Dignity with clear intent of breaking away from the horrific past. The Basic Law of Germany provides that 'human dignity shall be inviolable. To respect and protect it shall be the duty of all state authority'. ${ }^{26}$ Human dignity is also the first provision of the Basic Law and this has symbolic meaning indicating its importance. Further, a clear obligation is imposed on state organs to make its respect and protection their prime mission.

The status of human dignity is also unique in the German basic law as it is 'supreme, absolute, and eternal'. ${ }^{27}$ Human dignity sits at the top of the normative order and guides the relationship between states and individual as well as among individuals. The German basic law provides a 'blueprint' to what kind of society it desires to create i.e. a society committed to the value of human dignity. ${ }^{28}$ As such, human dignity radiates across the entire constitutional order and serves as the supreme guiding principle. Human dignity is also absolute in Germany because it is not susceptible to any kind of limitation. ${ }^{29}$ Thus, any limitation of right that affects human dignity or the central core of the right is regarded as unacceptable. Even more, the status of human dignity in the German basic law could not be altered even by amending the Basic Law. ${ }^{30}$ This is why human dignity is regarded as eternal in the German constitutional system.

Likewise, human dignity has a very prominent role in the South African constitutional order. After the end of the Apartheid regime in 1994, the new

${ }^{25}$ Barak, supra note 4, at 49-65.

${ }^{26}$ Basic Law for the Federal Republic of Germany 1949, art 1.

${ }^{27}$ Horst Dreier (2014), 'Human dignity in German Law' in Marcus Düwell and others (eds), The Cambridge Handbook of Human Dignity: Interdisciplinary Perspectives (Cambridge University Press) 375-384.

${ }^{28}$ Edward J. Eberle (1997), 'Human Dignity, Privacy, and Personality in German and American Constitutional Law' 4 Utah Law Review: 963-1056

${ }^{29} \mathrm{Ibid}$

${ }^{30}$ Basic Law, supra note 26, art 79(3). 
South African Constitution made Human Dignity one of the founding values. It states that South Africa is founded on 'human dignity, the achievement of equality and the advancement of human rights and freedoms'. ${ }^{31}$ This was done to clearly reject the South African past under the apartheid era where the dignity of the black South Africans was grossly violated through discriminatory laws and practices. The South African Constitution also clearly recognizes the right to human dignity in unequivocal terms by stating that 'everyone has inherent dignity and the right to have their dignity respected and protected'. ${ }^{32}$ The concept has also an important role in the interpretation and application of other constitutional rights.

Aside from the German and South African constitutions, many other constitutions also incorporate human dignity either as a constitutional right or as a constitutional value. ${ }^{33}$ The 2010 Constitution of Kenya is a good example in this regard. It is to be noted that most contemporary constitutions recognize human dignity either expressly or impliedly, and this shows the important constitutional status it has acquired globally.

The meaning of respect to human dignity and its manifestations in concrete terms (i.e., the essence of respect for human dignity) are among the most difficult and controversial themes in academic discourse. For some human dignity is an empty concept devoid of any tangible content or meaning. ${ }^{34}$ The argument here is that human dignity is so abstract that no one knows what it means in precise terms. Supporters of this view argue that the concept is susceptible to abuse and manipulation as it could mean anything.

Contrary to this position, there are scholars who argue that imprecision of meaning is not something peculiar to the concept of human dignity and it is partly attributable to the relative newness of it as a legal concept. ${ }^{35}$ Over the years, different courts across the globe have contributed a lot to the explication of the meaning of human dignity as a constitutional concept. The works of various scholars have also greatly assisted in the concretization of the core content of human dignity. These core aspects of human dignity include the respect for the life and integrity of the human person, recognition

\footnotetext{
${ }^{31}$ The Constitution of the Republic of South Africa (CRSA) 1996, art 1(a)

${ }^{32} I d$., art 10 .

${ }^{33}$ Barak, supra note 4 , at $49-65$.

${ }^{34} \mathrm{Id}$. at $8-10$.

${ }^{35}$ Ibid.
} 
of the equal worth of human beings and respect for the autonomy or selfdetermination of human beings. ${ }^{36}$

The first aspect of human dignity recognizes the 'intrinsic value of human life'. Human life is so valuable that neither a state nor any other individual should be allowed to deprive it. This dimension of human dignity was emphasized in the Makwayne decision of the South African Constitutional Court which outlawed death penalty. ${ }^{37}$ According to this decision, besides the protection of human life, to respect the dignity of a human being also means to preserve his or her physical and emotional integrity. Respect for physical integrity protects the person from cruel and inhuman acts that cause a bodily suffering. The respect for emotional integrity on the other hand seeks to protect human beings from degrading or humiliating treatment. ${ }^{38}$ Thus, one concrete meaning of human dignity is protecting human life, physical and emotional integrity.

The second important dimension of human dignity is recognition of the equal worth or value of human beings at both individual and group levels. To treat a person with dignity means to accept equality with others in respect of human quality. ${ }^{39}$ Much of unjust discriminations on the basis of race or gender are based on the idea that not all humans are equal in their humanity. The underlying assumption of the Jim Crow laws in the United States which prevented the African Americans from fully participating in the life of the American society on equal basis was the thinking that they are inferior to the white Americans in their worth or dignity. ${ }^{40}$ Thus, the conception of human dignity as equal value or worth challenges this assumption and asserts that no one is inferior or superior to others in his/her human quality, dignity or worth. Thus, to respect human dignity means to recognize the equal worth and value of fellow human beings.

The third core concertized aspect of human dignity is respect for individual autonomy or self-determination which may be exercised individually or collectively. At individual level, this dimension of human dignity gives the individual the freedom to make fundamental decision in his

\footnotetext{
${ }^{36}$ Mahlmann, supra note 8, at 379-383.

${ }^{37}$ S v. Makwanyane, 1995 (3) SA 391 CC.

${ }^{38}$ McCrudden, supra note 15, at 683, 685-689.

${ }^{39}$ Matthias Mahlmann (2014), 'The Good Sense of Dignity: Six antidotes to dignity fatigue in law and Ethics' in Christopher McCrudden(eds), Understanding Human Dignity, Reprint edition (Oxford: British Academy), p. 596

${ }^{40}$ Cecil J. Hunt II (2016), 'The Jim Crow Effect: Denial, Dignity, Human Rights, and Racialized Mass Incarceration', $29 \mathrm{~J}$. Civ. Rts. \& Econ. Dev:15, 15-49.
} 
life by himself and be self-directed. ${ }^{41}$ With the recognition of autonomy, the individual will be free to develop his personality in manner he or she sees it fit and live his life according to his choice. His freedom of thought, expression, belief and association will be fully protected. It also safeguards the autonomy of individual to make personal choices. In some constitutional systems, the recognition of the human dignity as an autonomy is interpreted to allow terminally ill individual to decide to end their life and recognize the right of the mother to terminate pregnancy or undertake an abortion. ${ }^{42}$

Thus, to respect human dignity means to respect the autonomy of the person. Yet, it must be noted that autonomy (as an integral part of human dignity) is meant to be exercised 'within the framework of a society' ${ }^{43}$ This means legitimate and reasonable limits could be imposed on the autonomy of an individual to preserve the autonomy of others as well as make possible living in a community. At collective level, this aspect of human dignity entitles the group to maintain its distinct identity and govern itself. ${ }^{44}$ These entitlements could further be divided into different components of the right to self-determination. The rights include 'the protection of the cultural, religious, linguistic, and ethnic identity of individuals and groups; and ... the right of individuals and groups to participate effectively in the economic and the political life of the country'. ${ }^{45}$

The above being the core aspects or meanings of respect for human dignity as a constitutional concept, the next discussion would be on what role human dignity is playing in major constitutional systems such as Germany and South Africa. From the case law of the constitutional courts of the Germany and South Africa as well as from the scholarly works written on the subject, it is possible to infer that human dignity serves foundational, interpretative and generative functions in these systems. ${ }^{46}$ As a foundational concept human dignity serves as a justification for human rights. Thus, the question why we have human rights is often answered primarily by saying

${ }^{41}$ McCrudden supra note 15, at 683, 685-689.

${ }^{42}$ Ibid.

${ }^{43}$ Donald P Kommers and Russell A. Miller (2012), The Constitutional Jurisprudence of the Federal Republic of Germany, (Third Edition, Duke University Press Books), 42-76.

${ }^{44}$ Micha Werner (2015), Individual and Collective Dignity, in Marcus Duwell (eds), The Cambridge Handbook on Human Dignity Interdisciplinary perspectives (Cambridge University Press) 343-354.

45 Hurst Hannum (1998), 'The Right of Self-Determination in the Twenty-First Century', 55 Wash. \& Lee L. Rev. 773,777.

${ }^{46}$ Barak, supra note 4, at 103-113. 
that because we have dignity and our dignity entitles us to proper or respectful treatments recognized in the form of human rights. It is also important to bear in mind that, at the drafting process of the UDHR, human dignity was the only foundation for human rights that was accepted or found to be appealing to the participating states from diverse cultural roots. ${ }^{47}$ The second vital function of human dignity is its use in interpreting human rights embodied in national constitutions and international treaties.

For example, the Constitutional Court of South Africa utilizes human dignity to differentiate between fair and unfair discrimination. ${ }^{48}$ According to the jurisprudence of the court, the differential treatment of two persons becomes problematic under the constitution only when the dignity of one of them is infringed. A similar test is also used by other courts including Kenya. Beside its use in delineating the scope and meaning of human rights, human dignity is also utilized to assess the propriety of limitation imposed on constitutional rights. In relation to this, the Constitution of Kenya provides that 'right or fundamental freedom in the Bill of Rights shall not be limited except by law, and then only to the extent that the limitation is reasonable and justifiable in an open and democratic society based on human dignity, equality and freedom' ${ }^{49}$ From this statement, we can see that one of the factors taken in to account in the determination of whether a limitation is acceptable or not is to see its impact on the human dignity of the person. If the limitation disproportionately undermines the dignity of the person, then the limitation becomes invalid.

The last crucial function of human dignity is its generative or adaptive function in the context of constitutional rights. Due to the change in social, political, cultural or social factors, there might arise a need to recognize new set of rights. In the constitutional systems discussed above, human dignity serves this function by enabling the judges to discover new set of rights from it through the exercise of purposive interpretation that seeks to identify the

${ }^{47}$ Stu Woolman (2013), 'The Architecture of Dignity' in Drucilla Cornel (eds), The Dignity Jurisprudence of the Constitutional Court of South Africa Cases and Materials, Vol. I (Fordham University Press), 73-123.

${ }^{48}$ Laurie Ackerman (2012), Dignity the loadstar for equality in South Africa, (JUTA cape town,) 115-162; R. O'Connell (2008), 'The Role of Dignity in Equality Law: Lessons from Canada and South Africa' 6(2) $I \cdot C O N, 267,267-286$; P. De Vos (2014), 'Equality , Human Dignity and Privacy Rights', in Pierre De Vos, Warren Freedman, and Danie Brand (eds.) South African Constitutional Law in Context, (Oxford University Press), 417-466.

${ }^{49}$ Constitution of Kenya 2010, art 24 (1). 
objects of rights in a democratic society. ${ }^{50}$ This in turn ensures the responsiveness of a constitutional system to changes that can unfold thereby maintaining its currency.

\section{Revisiting the Foundations of the FDRE Constitution from the Perspective of National Unity and Human Rights}

\subsection{The underlying historical narrative of the FDRE Constitution}

In order to examine the foundations of the present Ethiopian constitution from the perspective of national unity and human rights, it is appropriate to begin with the reading of Ethiopian history on the part of the political actors which dominated the constitution making process. Generally speaking, the political forces which resisted the Derg military regime could be categorized as liberation fronts and underground political parties based on their agenda as well as name. ${ }^{51}$ The first class includes the Tigrean People Liberation Front (TPLF), Oromo Liberation Front (OLF) and the Ogaden National Liberation Front among others. In the second category includes political groups such as the Ethiopian People's Revolutionary Party (EPRP) and All Ethiopian Socialist Movement (AESM).

Most of these political organizations trace their origin from the Ethiopian student movement that gained momentum in 1960s and made great contribution to the overthrowal the imperial regime. ${ }^{52}$ In the bitter fight against the Derg rule, the political parties that were organized on non-ethnic basis such as the EPRP were crushed and eliminated by the Derg. ${ }^{53}$ This may be partly due to the urban-based struggle they opted to fight the Derg and other additional factors. In contrast, the liberation fronts that mainly resisted the regime in the rural areas of the country became the ultimate winners of the bloody civil war which ended in 1991 with the defeat of the Derg. ${ }^{54}$ This gave these political organizations the upper hand in shaping the content of the FDRE Constitution according to their narrative of the Ethiopian history/past.

Since the time of the Ethiopian student movement, the liberation fronts had subscribed to the narrative about the past Ethiopian state, which was

\footnotetext{
${ }^{50}$ Barak, supra note 4, at 109.

${ }^{51}$ Andargachew Tiruneh (1993), The Ethiopian Revolution 1974-1987, (Cambridge University Press) xii-xiii, 24, 138,174.

${ }^{52}$ Ibid.

${ }^{53} \mathrm{Ibid}$.

${ }^{54}$ Gebru Tareke (2009), The Ethiopian Revolution War in the Horn of Africa, (Yale University Press), 76-110.
} 
initially articulated by one of the leaders of the Ethiopian student movement Walleleign Mekonen. ${ }^{55}$ In his piece 'On the Question of Nationalities in Ethiopia', he had identified the core problem of the Ethiopian states to be the Amhara domination and subjugation of other ethnic communities residing in Ethiopia. He argued that the supremacy is manifested not only politically but also culturally, stating that "to be a 'genuine Ethiopian' one has to speak Amharic, to listen to Amharic music, to accept the Amhara-Tigre religion, Orthodox Christianity and to wear the Amhara-Tigre Shamma; ... in short to be an Ethiopian, you will have to wear an Amhara mask". ${ }^{56}$

Along the same line, some liberation-oriented political organizations even take this narrative further and claim that the issue they have with the Ethiopian state is that of 'internal colonization'. They argue that 'Amhara' Ethiopian kings such as Emperor Menilik had subjected and annexed independent political communities such as the Oromos under their rule through means of force. ${ }^{57}$ For these groups, the only way to remedy this is full independence from Ethiopia and the establishment of their own state.

\subsection{Reflections on the historical narrative in the design of the FDRE Constitution}

As some scholars argue, the ethno-nationalist political organizations that won the fight against the Derg dominated the making of the FDRE Constitution. ${ }^{58}$ This means their view or narrative about the Ethiopian past has served as the basis of the FDRE Constitution. Other political forces with alternative vision were systematically excluded from the process and had no meaningful voice or input. So it is only natural that the FDRE Constitution reflects the narrative of ethnic-based political organizations and provides maximum protection for the interest of the group they claim to represent. Several parts of the Constitution attest to this fact.

${ }^{55}$ Walleleign Mekonen (1969), 'On the Question of Nationalities in Ethiopia', Arts IV, HSIU Nov. 17, 1969, 2.

${ }^{56}$ Ibid.

${ }^{57}$ Alemayehu Kumsa (2010), 'The Conflict Between the Ethiopian State and The Oromo People', ECAS 2013, 5th European Conference on African Studies, A. Jalata, Contending Nationalisms of Oromia and Ethiopia. Struggling for Statehood, Sovereignty, and Multinational Democracy, (Binghamton); Alem Habtu (2005), 'Multiethnic Federalism in Ethiopia: A Study of the Secession Clause in the Constitution' 35(2) Publius, 313-335.

${ }^{58}$ Gedion T Hessebon (2013), 'The Precarious Future of the Ethiopian Constitution', 57(2) Journal of African Law: 215-233. 
The Preamble of the Constitution starts with the statement 'We the Nation, Nationalities and Peoples of Ethiopia'. ${ }^{59}$ This formulation is unique compared to many other constitutions. The trend in other constitutions is to refer to the 'People' or 'Citizens' of the country as one entity irrespective of the existing diversity. However, in the FDRE Constitution, the terms Nation, Nationalities and Peoples (NNPs) was preferred rather than recognizing the entirety of the Ethiopian people as one unified whole. ${ }^{60}$ In addition, the FDRE Constitution has also given the NNPs the ultimate say on any crucial matter in the Ethiopian polity. It provides 'all sovereign power resides in the Nations, Nationalities and Peoples of Ethiopia' ${ }^{61}$

The core historical narrative that underpins the Constitution is also manifested in the organization of states as well as in the extent of power given for ethnic communities. One typical feature of the FDRE Constitution is its design of the federal structure along ethnic and language composition of the people living in those territories. The bigger states of the federation in terms of population number and area are inhabited by one dominant ethnic group with the exception of the State of Southern Nations, Nationalities and Peoples (SNNP). ${ }^{62}$

The NNP's were also granted the full right to self-determination including self-governance, that could go up to the extent of seceding from the country upon the fulfilment of certain formal requirements. In this regard, the FDRE Constitution states, 'every Nation, Nationality and People in Ethiopia has an unconditional right to self-determination, including the right to secession'. ${ }^{63}$ To the best of the writer's knowledge, such degree of autonomy and self-determination to ethnic communities within a framework of a country is unprecedented (with the exception of the USSR Constitution under Stalin which has ultimately led to Soviet Union's disintegration). Unconditional right to self-determination is not also supported by the current understanding international law. ${ }^{64}$

According to some writers, the right to secession was included in the Constitution because some ethnic based liberation fronts made it a

\footnotetext{
${ }^{59}$ Constitution of the Federal Democratic Republic of Ethiopia (FDRE const.) 1995, preamble

${ }^{60}$ Fasil Nahum (1997), Constitution for a Nation of Nations: The Ethiopian Prospect (The Red Sea Press) 39, 51.

${ }^{61}$ FDRE Constitution, supra note 59, art 8 (1).

${ }^{62} \mathrm{Id}$. art $46(2) \& 47$ (1).

${ }^{63} \mathrm{Id}$. art 39 (1).

${ }^{64}$ Hannum, supra note 45, at 776.
} 
precondition for their approval of the Constitution and threatened immediate secession unless their demands are met. ${ }^{65}$ In addition to all these, the Constitution also give the final say on constitutional disputes to the House of Federation which is a body composed of the NNPs. The Constitution stipulates that 'the House has the power to interpret the Constitution'. ${ }^{66}$ All these provisions show the broadly extended power that was given to the ethnic communities in the FDRE Constitution, which is partly attributable to the vision and narrative of political forces that dominate its making.

\subsection{The impact of the historical narrative and the design of the FDRE Constitution on national unity and human rights}

National unity is one of the issues which received inadequate attention by the framers of the FDRE Constitution. For any strong state-nation to emerge, it presupposes a strong commitment to building a sense of 'national identity' or 'unity' among its people irrespective of their diversity in ethnicity, culture, religion or physical appearance. ${ }^{67}$ It is for these reasons that many constitutions give a central place to the promotion and preservation of national unity. A good example in this regard could be the preamble of the Indian Constitution which underlines the commitment of India to maintain 'the unity and integrity of the Nation'. ${ }^{6}$

It is to be noted that India is one of the most diverse societies divided along ethnic, religious and other lines. Its Constitution further makes it the explicit duty of citizens 'to uphold and protect the sovereignty, unity and integrity of India'. ${ }^{69}$ A similar constitutional recognition of national unity is also found in the South African constitution. The preamble states:

'We the People of South Africa ... believe that South Africa belongs to all who live in it, united in our diversity. ...We therefore ... adopt this Constitution ... to ... heal the divisions of the past and establish a society based on democratic values, social Justice and fundamental human rights' and seek 'to build a united and democratic South Africa

\footnotetext{
${ }^{65}$ Alem Habtu (2005), 'Multiethnic Federalism in Ethiopia: A Study of the Secession Clause in the Constitution', 35(2) Publius: 313-335, 324.

${ }^{66}$ FDRE Constitution, supra note 59, art 62(1).

${ }^{67}$ Bhikhu Parekh, 'Nehru and the National Philosophy of India'(Jan. 5-12, 1991), Economic and Political Weekly 35-39,41-43,45-48; Jawaharlal Nehru (1985), The Discovery of India, (Oxford University Press)

${ }^{68}$ The Constitution of India 1949, preamble

${ }^{69} \mathrm{Id}$. art 54 A. (c).
} 
able to take its rightful place as a sovereign state in the family of nations'. 70

Both the Indian and South African Constitutions underscore the need for national unity and maintaining the integrity of the state in unequivocal terms. Further, both constitutions begin with similar phrase 'We the People'. This has a symbolic importance because it conveys the message that, the people of South Africa or India are one people committed to creating one state-nation, despite their cultural or other differences. More importantly, both constitutions speak in terms of citizenship to distribute sovereignty and rights in the polity. For instance, the Indian Constitution says ' $W e$, the People of India, having Solemnly resolved to Constitute India into a Sovereign Socialist Secular Democratic Republic and to secure to all its Citizens ... Justice ... Liberty ... Equality... Fraternity'... . ${ }^{71}$

Here, we can see that the primary identity in the framework of the nationstate is citizenship not ethnic identity. Along the same line the South African Constitution seeks to create 'a democratic and open society in which government is based on the will of the people and every citizen is equally protected by law' and to 'improve the quality of life of all citizens and free the potential of each person' 72 The language used in both constitutions is immensely important as it clearly demonstrates the strong emphasis and place they give for national unity, by making citizenship the sole criteria of seeking rights and privilege in their constitutional order.

The stipulation of the FDRE Constitution stands in clear contrast to the position of the two constitutions discussed above. As noted above, its preamble begins with the statement 'We, the Nations, Nationalities and Peoples of Ethiopia'. ${ }^{73}$ The choice of words here is deliberate and the drafters seems to emphasize the distinct identity of ethnic communities residing in the country. It also conveys the message that Ethiopian people do not have one 'national' or 'Ethiopian identity'. As such, the Ethiopian Constitution recognizes the people primarily as NNPs rather than Ethiopian citizens. The absence of any reference to citizenship in the preamble is notable in this regard.

This author argues that this manifests improper attention given to national unity in the Constitution. Yet, some may argue that the Constitution is formulated in this way because there is no real 'Ethiopian identity' or sense

\footnotetext{
${ }^{70}$ CRSA, supra note 31 , preamble.

${ }^{71}$ The Constitution of India, supra note 68, preamble.

${ }^{72}$ CRSA, supra note 31 , preamble \& art 3(2).

${ }^{73}$ FDRE Constitution, supra note 59, preamble.
} 
of belongingness to the Ethiopian state among the different ethnic communities inhabiting the nation. They argue that the nation-building project of the past Ethiopian regimes with the use of force and assimilation has failed to create an Ethiopian identity and the Constitution is just a reflection of this reality. Even if one may consider this argument plausible, the approach of the constitutional framers is not appropriate since they have not laid down the groundwork for the creation of a strong Ethiopian identity founded on certain democratic values. This issue is discussed in more depth in the fourth section of the article.

The other problematic aspect of the present Ethiopian Constitution from the angle of national unity is the reference made (in the Preamble) about the 'strong commitment' of the NPPs 'to building a political community'. ${ }^{74}$ The crucial question here is whether the phrase 'political community' is a synonym of a state-nation. If it means the same thing, we may not have that much problem. However, the question remains why the framers preferred the phrase 'political community' instead of saying the state of Ethiopia, which is a common formulation in many other constitutions. I argue that a political community is not identical to the concept of a state-nation. The existing literature on the subject also seems to support this conclusion. For instance, as Kukathas notes 'a political community is essentially an association of individuals who share an understanding of what is public and what is private within that polity. ${ }^{75} \mathrm{He}$ further argues that a political community could exist independent of a state and a government. Thus, a political community seems to be a loose form of political association.

This could be contrasted with the conception of state-nation where recognition is given to national units in a manner that does not threaten or 'hollow' the existence of the state. ${ }^{76}$ In such states, citizens have no problem of attaching or identifying themselves with the state. Considering this, the framers of the FDRE Constitution seem to have the intention of creating a pure multinational Ethiopian state, which is more like a confederation of various ethnic communities inhabiting it. The state is conceived as 'a sum of nations, each with its own exclusive identity, symbols and laws'. ${ }^{77}$ In such a state, the prime identity marker in the polity would be national identities

\footnotetext{
${ }^{74}$ FDRE Constitution, supra note 59, preamble.

${ }^{75}$ Chandran Kukathas (2003), 'Political Community' in Chandran Kukathas (eds.) The

Liberal Archipelago: A Theory of Diversity and Freedom (Oxford) 172-173

${ }^{76}$ Stephan et al, supra note 1, at 11-12.

${ }^{77}$ Ibid.
} 
rather than citizenship. Such arrangement encourages people to be loyal primarily to their ethnic group rather than the state. This in turn undermines the unity of the country and its existence.

The weak place given to national unity is also manifested in the seemingly limitless power given to the NPPS. Although the constitutional recognition given to them to self-administer and develop their culture and languages is a positive thing, the Constitution goes to the extent of accepting their 'unconditional... right to secession' ${ }^{78}$ I argue that this demonstrates the lack of commitment on the part of the framers of the Constitution to maintain the Ethiopian state as well as its territorial integrity. Contrary to the Ethiopian Constitution, in many multi-ethnic states, a constitution unequivocally recognizes the indivisibility of the country. For instance, the Kenyan constitution provides that 'We, the people of Kenya, proud of our ethnic, cultural and religious diversity, and determined to live in peace and unity as one indivisible sovereign nation'. ${ }^{79}$ This provision is a classic example that shows a strong commitment to national unity while recognizing diversity. In light of these standards, the level of protection of national unity in the FDRE Constitution is grossly inadequate.

Even though organizing regional states of the Ethiopian federation along ethnic lines may not have been inherently problematic (and not something unheard of), the stipulation of some state constitutions raises an alarm on the status of national unity. As provided in the FDRE Constitution, states are mandated to adopt their own regional constitution. ${ }^{80}$ Accordingly, all of the states have constitutions applicable within their respective territories. One problematic aspect of these constitutions is their apportionment of sovereign power. For instance, the Revised Constitution of Oromia Regional State provides that 'Sovereign Power in the region resides in the people of the Oromo Nation'. ${ }^{81}$

Although, the right of other Ethiopian citizens to move within these states, to live and own property is recognized, ${ }^{82}$ the bestowment of sovereign power to one ethnic group, may automatically convey the message that others are outsiders and less privileged. Such formulations may also foster the thinking that other ethnic groups have lesser right compared to the 'native' ones and this can induce eviction, as it has already happened in

\footnotetext{
${ }^{78}$ FDRE Constitution, supra note 59, art 39.

${ }^{79}$ Constitution of Kenya, supra note 49 , preamble.

${ }^{80}$ FDRE Constitution, supra note 59, art 50 (5).

${ }^{81}$ The Revised Constitution of Oromia Regional State, 2001, art 8

${ }^{82} I d$. art 33.
} 
some of the regional states. It could also be an obstacle for national unity and could possibly ignite a further division. A better formulation is provided in the Constitution of the Amhara Regional State which states that 'the supreme power of the national regional state resides and belongs to the peoples of the Amhara region'. ${ }^{83}$ What makes this regional constitution different is that sovereign power is bestowed on the people residing in the region irrespective of their ethnic identity. Thus, due to the very design of the FDRE Constitution and its underlying historical assumptions as well as problems related to its implementation, it has contributed towards the fragility of national unity in the Ethiopian polity.

The other recurring problem in the Ethiopian state is the inadequate protection of Human Rights. The FDRE Constitution is praised for devoting a significant part for enumerating a wide range of human rights. ${ }^{84}$ The Constitution indeed encompasses civil, political, social economic and cultural rights. It also incorporates individual and group human rights. The constitutional supremacy of international human rights ratified by Ethiopia in the interpretation of human rights enshrined in the Constitution also deserves to be admired ${ }^{85}$ In this sense, the Constitution could be regarded as comprehensive.

However, the enumeration of rights in a constitution is not an end itself. It is only when the constitutional rights stated in a constitution succeed in restraining the arbitrary exercise of power by a state that one can really appreciate their importance. In this regard, the FDRE Constitution has failed to bring about fundamental transformation in the protection of human rights in the country. As reported by different international and local human rights monitoring bodies, the Ethiopian state is notorious for its gross violation of human rights. ${ }^{86}$ Ranging from civil rights such as the right to freedom of expression, assembly, association to socio-economic rights such as the right to water and housing, Ethiopian state performance is weak to say the least.

\footnotetext{
${ }^{83}$ Revised Constitution of the Amhara National Regional State (2010) art.8 (1)

${ }^{84}$ Adem Kassie Abebe (2011), 'Human Rights under the Ethiopian Constitution: a Descriptive Overview', 5(1) Mizan Law Review, 41-71.

${ }^{85}$ FDRE Constitution, supra note 59, art 13 (2).

${ }^{86}$ Human Rights, World Report 2018: Ethiopia https://www.hrw.org/worldreport/2018/country-chapters/ethiopia \& Human Rights Council-HRCO142 ${ }^{\text {nd }}$ Special Report (Executive Summary)Human Rights Violations committed during the State of Emergency in Ethiopia https://ehrco.org/wp-content/uploads/2017/07/HRCO-142ndSpecial-Report-English-Executive-summary-2.pdf
} 
Even worse, the absolutely prohibited acts of torture and inhuman treatment were practiced in different detention centers of the nation ${ }^{87}$ until they were officially denounced as part of the post-2018 reforms. The important question we should be asking ourselves is 'why did the country fail to make advancement in this respect?' Several factors could be mentioned for this disconcerting state of affairs. Yet, this article focuses on substantive issues without touching on institutional issues in depth.

One of the substantive problems in the FDRE Constitution with respect to human rights is its bias towards group rights at the expense of individual rights. ${ }^{88}$ This is partly attributable to the founding grand narrative of the Constitution, which considers the violation of the right of the NNPs in the past regimes as the core problem of the nation. Based on this assumption, the Constitution went a great length to protect the group rights of NNPs to selfdetermination including secession. This resulted in lack of sufficient attention to the importance and protection of individual rights enshrined under the Constitution. ${ }^{89}$ The obsession of the state officials as well as media (during the early 1990s) was towards promoting the right of NNPs in every possible platform. This was partly because of the failure to understand the essence of human rights, which is primarily to protect the individual against the tyrannical act of the state or the community he or she is living in. ${ }^{90}$

The extended right to self-determination given to ethnic based states, has also created problems in the exercise of certain rights. These rights include the right to freedom of movement, the right to life, the right to property and the right to security. ${ }^{91}$ In different regional states of the Ethiopian federation, individual citizens are being forcefully evicted from the land they possess merely because of their ethnic identity. The eviction of the Oromos from the Somali state and the Amhara's from the Benshangul/Gumuz state are

${ }^{87}$ Befeqadu Hailu, 'The Torturous Fields of Ethiopia's Rehabilitation Center', https://www.amnesty.org/en/latest/campaigns/2017/02/the-torturous-fields-ofethiopias-rehabilitation-centre/

${ }^{88}$ Berihun Adugna Gebeye (2017), 'Toward Making a Proper Space for the Individual in the Ethiopian Constitution' 18(4) Human Rights Review, 439-458.

${ }^{89}$ Ibid.

${ }^{90}$ Louis Henkin (1989), 'The Universality of the Concept of Human Rights', 506 The Annals of the American Academy of Political and Social Science, Human Rights around the World (Nov., 1989) 10-16

${ }^{91}$ Yonas Girma Adimassu (2013), Implication of Ethiopian Federalism on the Right to Freedom of Movement and Residence: Critical Analysis of the Law and the Practice, LLM Thesis Submitted to Addis Ababa University College of Law and Governance. 
examples of this tragic trend. ${ }^{92}$ In the process of such eviction lives are lost; and property is looted and destroyed. This is utterly incompatible with the right to life and property protected under the FDRE Constitution.

The other issue that inhibited adequate protection of human rights in Ethiopia is the lack of clear foundation in the Constitution and the absence of an adequate guiding principle for the interpretation and limitation of rights. In the FDRE Constitution, there is a provision which links human rights with human nature. It states, 'human rights and freedoms, emanating from the nature of mankind, are inviolable and inalienable'. ${ }^{93}$ Although this statement is positive in tracing human rights to 'human nature', it lacks specificity and does not explicitly indicate the purpose human rights are intended to serve. A better formulation is provided in the 2010 Kenyan Constitution, which reads 'the purpose of recognizing and protecting human rights and fundamental freedoms is to preserve the dignity of individuals and communities and to promote social justice and the realization of the potential of all human beings' ${ }^{94}$ This provision clearly articulates the purpose of constitutionally recognizing human rights which aims at safeguarding the dignity of human beings thereby enabling them to live a life worthy of promoting social justice and the realization of their potential.

The clear enunciation of the foundation and ultimate purpose of human rights further elevate the status of constitutional rights and force the state and other actors to take them seriously. It also serves as a bulwark for preventing arbitrary interpretation and limitation of rights. ${ }^{95}$ One of the disconcerting problems in the interpretation of constitutional rights in Ethiopia is the absence of a clear principle that guides the process. Although the Constitution has provided for the interpretation of human rights by giving due regard for international human rights treaties, the practice seems to stand in stark contrast to the stipulation of the Constitution. A clear guiding principle in the construction of the meaning, scope and delimitation of human rights is vital. Moreover, the arbitrary formulation of limitation

\footnotetext{
92 'Ethiopia 2013 Human Rights Report' https://www.state.gov/documents/organization/220323.pdf \& Dawit Rndeshaw, 'UN says million displaced in Oromia-Somali Conflict', 3 February 2018 https://www.thereporterethiopia.com/article/un-says-million-displaced-oromiasomali-conflict

${ }^{93}$ FDRE Constitution, supra note 59, art 10.

${ }^{94}$ Constitution of Kenya, supra note 49, art 19(2).

${ }^{95} \mathrm{Id}$. art 24(1)
} 
clauses or the Constitution has contributed its part for the status quo. ${ }^{96}$ For some rights the Constitution explicitly lists the grounds of limiting them and the procedure thereof. For others, the Constitution is silent with respect to the manner of limitation and this opens the door for arbitrary limitation. This needs to change if Ethiopia is to become a human rights respecting state.

\section{The Merits of Human Dignity-Centered Narrative, Constitutional Design and Interpretation}

In the preceding section, I have argued how the founding assumptions of the constitutional makers about Ethiopian past and the constitution design that emerged out of it have undermined national unity and contributed for the fragile state of human rights protection. This section, deals with some potential remedies to these problems relying on the constitutional value of human dignity. I argue that the starting point should be changing the grand narrative about Ethiopian past which is prevalent in the political discourse since the time of the Ethiopian student movement. At the heart of this narrative about the key problem of Ethiopian state since its establishment is the claim that, there has been, 'the domination of several ethnic groups by one or two groups which controlled political power' ${ }^{97}$ This narrative is a simplistic understanding of what really went wrong and does not promote national unity. It is simplistic in the sense that the problem with the Ethiopian state from the past until present is much bigger and complex than the oppression of one ethnic group by another.

The adequate lens for looking at the Ethiopian past in my view should be respect for human dignity which is richer and comprehensive. The argument here is that the central problem of the Ethiopian state since its formation is lack of respect for human dignity which is expressed or manifested in different forms. As highlighted earlier, to respect human dignity in essence means to respect the life and integrity of a human being, to recognize the equal worth and value of every person individually as well as collectively and to preserve individual and collective autonomy in a harmonious manner. Since the time of the imperial regime, the Ethiopian state has shown little or no respect for the life and physical integrity of its people. Both during the imperial regime and the Derg military rule many individuals who opposed the administration lost their precious lives and suffered grave bodily

\footnotetext{
${ }^{96}$ Tsega Andualem Gelaye (2016), 'Protection of the Right to Freedom of Assembly under Ethiopian Law: Gaps and the Way Forward', 10 (2) Mizan Law Review: 296340

${ }^{97}$ Walleleign, supra note 55.
} 
injuries. ${ }^{98}$ They were also subjected to cruelest forms of torture and inhuman treatment that caused intense suffering to the body and soul. Many were also subjected to humiliating treatment, killed and left on the street as if they had no value. These tragic incidents have also happened in the era of EPRDF to a certain extent. ${ }^{99}$

Several accounts could be made to demonstrate how the past Ethiopian state failed to recognize the equal value of human beings that emanates from their equal dignity. During the feudal era, some were landlords with all sorts of rights and privileges. ${ }^{100}$ Others were landless and tenants, subservient to the whim of their landlord in every possible way. There were also times when there were slave owners and slaves. The past Ethiopian state also did not recognize the equality and non-differentiated human dignity of all ethnic and linguistic groups. There were groups who were systematically excluded from political power, the development of their culture, language and tradition was inhibited. The Ethiopian state also did not embrace the equality of all human beings irrespective of gender and religious identity. Ethiopian women were excluded from position of political power, denied of equal opportunities to flourish and subjected to the whim of men. ${ }^{101}$

Equal recognition to the value of certain religious communities was also denied by the Ethiopian state. The discrimination endured by the Ethiopian Muslims could be mentioned as a good example. ${ }^{102}$ The unequal treatment of all is not only manifested at the state level. Condescending attitude towards others who are different in language, ethnicity, appearance, religion or the type of profession they engage in is also noticeable at the societal level and in the way we interact with each other which is inappropriate. Hence, one typical characteristics or problem of the Ethiopian state is its

\footnotetext{
${ }^{98}$ Andargachew, supra note 51.

${ }^{99}$ Befeqadu Hailu, supra note 87.

${ }^{100}$ Bahru Zewde (2002), A History of Modern Ethiopia 1855-1991 (Addis Ababa University Press) 87-94 \& Edmond J. Keller (1991), Revolutionary Ethiopia: From Empire to People's Republic (Indiana University Press).

${ }^{101}$ Meaza Ashenafi (2009), Factors Affecting Women Participation in Politics and Decision Making. A Dissertation of MA Thesis; Gennet Zewide (2014), Resistance, Freedom and Empowerment: the Ethiopian Women's struggle, Interview with Meaza Ashenafi, head of women lawyers association', http://www.irinnews.org/report/47120/ethiopia-'interview-meaza-ashenafi-headwomen-lawyers-association

102 Patrick Desplat and Terje Østeb (2013), Muslim Ethiopia: The Christian Legacy, Identity Politics, and Islamic Reformism (Palgrave Macmillan,)
} 
failure to recognize the equal dignity or worth of all human beings irrespective of their ethnic origin, religious identity and gender.

The other core problem of the Ethiopian state from the very start until now is its failure to recognize the autonomy and self-determination of the individual human being. Throughout the Ethiopian history individual freedom has been an alien notion. The individual human has always been subject to the whim of the community and the state he is living. In the imperial time the individual and the entire people were regarded as subjects of the Emperor. ${ }^{103}$ The individual was expected to align to state ideology, and was not given the real option to chart his way of life in a manner he sees fit. In certain instances, the Ethiopian state even went to the extent of forcing the individual to change his religious belief and his identity including his name to make it compatible with the preference of the state. ${ }^{104}$

The mandatory requirement (from the 1990s onward until post-2018 reforms) in various parts of Ethiopia to identity oneself with a certain ethnic group in the national identity card also manifests excessive state interference on individual autonomy. It is important to note that, a reasonable limit to individual autonomy is acceptable to any organized society. ${ }^{105}$ The problem in this regard relates to its extent and arbitrariness. Any arbitrary restriction which prevents individuals from making central choices about their life is a clear manifestation of lack of respect for individual human dignity and worth. Further, group claims of autonomy to develop culture, language, practice religion and administer their own affairs could be embraced within the framework of respecting human dignity to the extent it is reasonable.

Besides capturing the root of the problem in the Ethiopian state, human dignity centered view of the problems fosters national unity and enhances the adequate protection of human rights. Such narrative strengthens national unity because it, inter alia, does not blame one particular ethnic community for all the evils that happened in the nation. It does not also attribute the acts committed by the ruling elite to the entire ethnic group (to whom the ruler belongs). It is to be noted that the majority of the members of such community are as oppressed as others; and are in a more or less similar state of poverty.

The human dignity-centered perspective rather interprets common oppression as a factor that strengthens feeling of solidarity and unity. In

\footnotetext{
${ }^{103}$ Revised Constitution of Ethiopia 1955, preamble

${ }^{104}$ Abbas Haji Gnamo (2002), 'Islam, the Orthodox Church and Oromo Nationalism

(Ethiopia)' 165, XLII-1 Cahiers d'Études africaines, 99-120

105 McCrudden, supra note 15, at 700.
} 
addition to enhancing solidarity among the people, human dignity centered narrative helps to create a strong national Ethiopian identity irrespective of ethnic or religious diversity. As noted in the third section, the reason why some individuals in Ethiopia feel uncomfortable to identify themselves as Ethiopians is due to the belief that the identity is imposed upon them against their will.

However, we should not be fixated by the deeds of the past and close our minds from a better future. If the problem with Ethiopian identity is forceful imposition, it is possible to create a new and strong Ethiopian national identity through our own full consent. It is thus within the realm of possibility to close the darkest chapter of our history and chart a new beginning by committing ourselves to respecting human dignity of every person. This involves preserving the life and integrity of a human being, accepting the equal value of every person and respecting his/her autonomy. In many constitutional systems, human dignity was made the foundation of their new constitutional system for signifying rejection of unjust past and for marking a break with it. ${ }^{106}$ Indeed, the commitment to create a nation founded on human dignity attends to the need of everyone and it is allembracing. It protects our humanity as individuals and at group, national and global levels. As the Canadian Supreme Court noted:

Human dignity means that an individual or group feels self-respect and self-worth. It is concerned with physical and psychological integrity and empowerment. Human dignity is harmed by unfair treatment premised upon personal traits or circumstances which do not relate to individual needs, capacities, or merits. It is enhanced by laws which are sensitive to the needs, capacities, and merits of different individuals, taking into account the context underlying their differences. Human dignity is harmed when individuals and groups are marginalized, ignored, or devalued, and is enhanced when laws recognize the full place of all individuals and groups within Canadian society. ${ }^{107}$

In other words, Human Dignity safeguards core interests which are personal, interests which we share with our ethnic or religious community as

\footnotetext{
${ }^{106}$ Catherine Dupré (2013), 'Constructing the Meaning of Human Dignity: Four Questions' in Christopher McCrudden (eds.), Understanding Human Dignity (Oxford: Published for the British Academy by Oxford University Press), 113-121.

${ }^{107}$ Law v. Canada (Minister of Employment and Immigration) [1999] 1 SCR 497, at para. 51.
} 
well as interests which we share with the entire human race. Thus, commitment to human dignity could be the bondage that creates harmony and fraternity among the diverse Ethiopian ethnic communities. Such unity further facilitates economic development and enduring peace, as majority of the conflicts occurring in Africa and elsewhere are ethnic in nature. ${ }^{108}$ The identification of the Ethiopian state with human dignity will shift the discourse from the NNPS to that of democratic citizenship.

As noted earlier in the third section, the assertion of nationality is very essential to the creation of a strong state. It is also the primary identity which serves as a condition for the distribution of certain rights and privileges. Since the new Ethiopian identity will signify respect for human dignity, every reasonable person will be willing or even proud to identify himself as an Ethiopian citizen. This will resolve once and for all the skepticism of loyalty to the Ethiopian nation and create a robust national unity.

Besides promoting national unity, human dignity centered constitutionalism has also the potential to ensure adequate protection of human rights. As noted above (in the third section), although human rights take a significant portion of the present Ethiopian Constitution, they do not have much practical value as they stand now beyond decorating the document. They neither succeeded in restraining the arbitrary exercise of power by the government nor served as handy shields for individuals to challenge injustice. The extent of their enforcement by the judiciary is also disappointing to say the least. Three major arguments presented below demonstrate how human dignity centered constitutionalism can strengthen the state of human right in Ethiopia. In this regard, lessons can be drawn from countries with well-functioning constitutional rights protection system founded on the value of human dignity.

The first important function that human dignity could play in Ethiopia is a founding role. As a house needs a strong foundation, constitutional rights also need a firm base. Otherwise, they will be exposed to momentary desire, and goals of the state can be readily sacrificed. If human dignity is regarded as the founding value of a constitution, it will serve as an enduring and powerful justification of rights. ${ }^{109}$ It also conveys the message that constitutional rights are not there for decorative purpose to beautify the document. They have much more importance, as they are there to preserve the dignity and worth of a human being. Once rights have sufficient

\footnotetext{
${ }^{108}$ Wanjala S. Nasong'o (2015), The Roots of Ethnic Conflict in Africa, (Palgrave).

${ }^{109}$ Barak, supra note 4, at 104-113.
} 
grounding, the assumption is that they are not going to be trumped easily. ${ }^{110}$ It also conveys the message that when you are violating a constitutionally recognized human right arbitrarily, you are also taking away the humanity of the person and treating him as a mere object or animal.

As witnessed in other constitutional systems, the value of human dignity could further strengthen the protection of human rights by serving as interpretive guide. ${ }^{111}$ It is a well-known fact that constitutional rights are formulated in a very general manner. Their exact meaning and scope of application cannot be determined by merely looking at the constitutional text. ${ }^{112}$ This is partly attributed to the very nature of constitutions. It is the duty of the legislature to provide details for the operationalization of constitutional rights in a specific context while making laws and courts are also expected to play their roles in the course of adjudicating cases.

The constitutional rights under the present Ethiopian Constitution are no exception in this regard. Hence, the legislature and bodies entrusted with the task of constitutional interpretation have the mandate to give them content while discharging their respective responsibility. In doing so, both need some sort of guidance. I argue that the guidance should come from human dignity, as it is the foundation of all human rights in both international human rights treaties and many national constitutions.

According to Aharon Barak, a prominent human rights scholar and former judge of the Israeli Supreme Court, the proper understanding of constitutional rights is impossible without understanding human dignity, which is their very foundation. ${ }^{113}$ Thus, founding the Ethiopian constitutional system on human dignity would provide guidance for legislature and interpreters to enforce constitutional rights in their respective jurisdictions.

In the present set up, there seems to be no principle that guides both these bodies when they deal with constitutional rights. This has resulted in a very narrow conception of rights and their application. A reference to human dignity on the other hand would contribute to richer and robust constitutional rights jurisprudence. Making human dignity the center of constitutional system also assists in preventing capricious limitations on fundamental

\footnotetext{
${ }^{110}$ Ibid.

${ }^{111}$ Laurie Ackerman (2012), Dignity the loadstar for equality in South Africa, (JUTA Cape Town) 115-162.

112 Ibid.

${ }^{113}$ Barak, supra note 4, at107.
} 
rights. ${ }^{114}$ As discussed earlier (in the third section) of this article, the arbitrary limitation by the legislature and the inability of courts to hold the legislature accountable among the multitude of problems adversely affect the protection of constitutional rights in Ethiopia.

In any democratic society, legitimate restrictions on the exercise of fundamental rights are acceptable. Concerns from the protection of right of others to the general safety of the public may be possible grounds of limiting rights as stipulated in different international human right treaties and constitutions. ${ }^{115}$ Here the term legitimate is very crucial because it excludes those restrictions regarded as arbitrary or based on insufficient consideration. In many constitutional systems, the three-step proportionality analysis is utilized to evaluate the constitutionality of limits on fundamental rights, i.e. suitability, necessity and proportionality. ${ }^{116}$ Besides the proportionality test, some constitutional systems explicitly prescribe the need for any limitation to be compatible with human dignity.

The Constitution of South Africa for instance provides that 'the rights in the Bill of Rights may be limited only in terms of law of general application to the extent that the limitation is reasonable and justifiable in an open and democratic society based on human dignity, equality and freedom'. ${ }^{117}$ As such, whenever the legislature takes a measure that curtails constitutional rights, it must demonstrate that it does not infringe the human dignity of a person beside other considerations; courts are also mandated to assess the conformity of state action and measure with the supreme value of human dignity. Such measures are very essential to safeguard the adequate protection of constitutional rights in Ethiopia, as their limitation is tested against their very foundation or ultimate aim, i.e. human dignity.

Another way which human dignity centered constitutional discourse can assist is in serving as a source for expansion and discovery of new rights in Ethiopia. When constitutional rights are designed, they are intended to be applied to the societal and technological conditions prevalent at the time of their making. However, over time due to change in societal attitudes or technological sophistication, it may be necessary to expand the already existing rights or recognize new ones. This could be done by amending the constitution and periodically incorporating new rights.

\footnotetext{
${ }^{114} I d$. at $112-113$.

115 Aharon Barak (2012), Proportionality Constitutional Rights and their Limitations, (Cambridge University Press,)

116 Ibid.

${ }^{117}$ CRSA, supra note 31 , art 36.
} 
Yet, such practice of amending the constitution whenever new developments emerge is not easy. In many constitutional systems, amending a constitution is subjected to very strict procedural requirements. ${ }^{118}$ Thus, it would be inefficient to follow this track to make the constitution abreast with new developments in the arena of fundamental rights. The better option for this is utilizing the founding value -human dignity- to incorporate new rights without spending time and resources. In South Africa, for example, the principle of human dignity is serving this important function. ${ }^{19}$ To sum up, human dignity centered constitutionalism is the way forward for Ethiopia to ensure the adequate protection of constitutional rights as it plays a founding, interpretative and generative role.

\section{Avenues of Making Human Dignity the Center of the Ethiopian Constitution}

If human dignity becomes the center of the constitutional discourse, it promotes national unity and strengthens the respect for human rights as argued in the article. This evokes the next crucial issue as to how this could be achieved in practice. This author argues that there are two avenues: i.e. constitutional amendments/revision, or constitutional interpretation. These options have their own merits and downsides. Their level of effectiveness also varies. The most ideal and effective way is to make human dignity the building block of the Ethiopian constitutional order explicitly, by amending/revising the present constitution. For this, inspiration could be taken from the South African Constitution that states, 'the Republic of South Africa is one, sovereign, democratic state founded on the following values... Human dignity, the achievement of equality and the advancement of human rights and freedoms.' ${ }^{120}$ However, this change alone is not enough to ensure national unity in Ethiopia because other provisions of the FDRE Constitution which promote division and disunity in the country, should also be reconsidered.

This must start with the replacement of the phrase 'We the NNPs' in the preamble with 'We, the People of Ethiopia'. Such reference is also common in constitutions of multi-ethnic federations such as India, which says 'We, the People of India'. ${ }^{121}$ This formulation indicates the existence of

\footnotetext{
${ }^{118}$ Barak, supra note 4, at 23.

119 Ibid.

${ }^{120}$ CRSA, supra note 31 , art 36.

121 The Constitution of India, supra note 68, preamble.
} 
common/shared values and bondage among the Ethiopian people regardless of ethno-linguistic and religious diversity. As authors of the constitution, the phrase embraces all Ethiopian citizens including those with mixed ethnic identity and those individuals who do not want to identify themselves on the basis of ethnic identity. The phrase 'We, the People of Ethiopia' does not in any way suggest uniformity. Nor does it undermine the diversity in the nation. It does not also deprive the rights of various ethnic communities to self-administration, promotion of language and culture.

There should also be unequivocal statement about the unity of the nation and preservation of its territorial integrity. This calls for omitting the provision that recognizes the unconditional right of the NNPs to secede from the Ethiopian state. ${ }^{122}$ Although the right to self-determination to the extent of self-administration, promotion of language and tradition is acceptable, it should have a limit. That limit should be respecting the unity and the integrity of the Ethiopian state. The constitutions of many states also expressly assert the unity and indivisibility of the nation. For instance, the Ugandan constitution stipulates 'the State and citizens of Uganda shall at all times defend the independence, sovereignty and territorial integrity of Uganda.' ${ }^{123}$ A similar statement is also found in the Constitution of Kenya. The preamble states 'We, the people of Kenya, proud of our ethnic, cultural and religious diversity, and determined to live in peace and unity as one indivisible sovereign nation'. ${ }^{124}$ By doing so the constitution should clear any doubts about the importance of unity and territorial integrity of the state. Any claim for right should be entertained within the territory of the nation through a democratic process and secession must not be an option.

In addition to these changes, the Constitution should be amended to make 'democratic citizenship' founded on the value of human dignity, the primary criteria for acquiring any right and privilege in the Ethiopian state. This should be explicitly stated at the preamble of the Constitution as well as its substantive parts. A good example of such stipulation is found in the constitution of South Africa and India. The preamble of the Indian constitution states 'We, the people of India, having solemnly resolved to constitute India into a sovereign secular democratic republic and to secure to all its citizens' justice, equality, liberty and fraternity. ${ }^{125}$

\footnotetext{
${ }^{122}$ FDRE Constitution, supra note 59, art 10.

${ }^{123}$ Constitution of the Republic of Uganda 1995 preamble.

${ }^{124}$ Constitution of Kenya, supra note 49, art 24 (1).

125 The Constitution of India, supra note 68, preamble.
} 
Likewise, the South African constitution asserts democratic citizenship and recognizes the equal right of citizens in the following manner. 'All citizens are-(a) equally entitled to the rights, privileges and benefits of citizenship; and (b) equally subject to the duties and responsibilities of citizenship'. ${ }^{126}$ As such, it makes citizenship the only yardstick for the allocation of rights and duties in the republic of South Africa. Once the equal right of citizens is affirmed, other rights could be bestowed upon groups to accommodate ethnic, linguistic or religious diversity.

Here, a question about affirmative action and compensating past injustices could be raised. To the extent that such 'measure is narrowly tailored' ${ }^{127}$, targeted transparent and time bound, a special benefit could be provided for the disadvantaged communities be it ethnic, religious or otherwise. This will not be incompatible with the idea of equal right of citizens. Further, the protection of the equal rights and treatment of all citizens may demand revisiting the current ethnic based federal structure which seems to neglect the rights of minorities and non-indigenous people. As it stands today, most state constitutions empower one ethnic group or a group of minority communities which are regarded as the indigenous people or owners of the region. ${ }^{128}$ Those individuals and communities who do not belong to the empowered ethnic group are considered as settlers and do not often receive equal treatment. In order to solve this problem, amending the provision of the federal and state constitutions in a manner that balances the interest to the majority and the minority as well as the interest of the group and the individual is essential.

The only problem with amending the Constitution in the way proposed above is the difficulty of the procedural hurdles and the possible lack of political will. ${ }^{129}$ One of the challenges relating to the present Ethiopian Constitution before the reform was its portrayal by the ruling EPRDF regime as sacred document needing no touch or revision. Any proposal for constitutional amendment was often rejected. ${ }^{130}$ However, this attitude seems to have changed after the reform and there is a willingness on the part of the ruling party to revisit the FDRE Constitution as part of an effort to

\footnotetext{
${ }^{126}$ CRSA, supra note 31 , preamble.

${ }^{127}$ Regents of the University of California v. Bakke 438 US 265 (1978).

${ }^{128}$ Christophe van der Beken (2017), Completing the Constitutional Architecture: A Comparative Analysis of Sub-national Constitutions in Ethiopia, 65, 74, 75.

${ }^{129}$ Nigussie Afesha (2016), 'The Practice of Informal Changes to Ethiopian Constitution in the Course of Application' 10(2) Mizan Law Review: 366-399.

${ }^{130} \mathrm{Id}$. at 384 .
} 
address the multifaceted problems of the country. As such, it seems likely to have a constitutional reform in the near future.

Yet, the procedure set for amending provisions like article 39 of the FDRE Constitution is difficult to meet, if not impossible. According to article 105(1)(a), the amendment of fundamental rights provision of the constitution require the agreement of all State Councils. If one state council objects to the proposed amendment while all others are agree, the amendment cannot proceed forward. Although the effort to entrench fundamental rights by providing strict amendment requirements is commendable, it must not go to the extent of precluding amendment completely. This is because it may lead the people to resort to violent means to change the Constitution. ${ }^{131}$

This raises the question relating to the feasible option towards the constitutional changes proposed in this article that can be implemented through the mechanism amendment. Richard Albert's views on extra constitutional and political amendments may give us an insight. ${ }^{132}$ According to this theory, it may be possible to amend a constitution through extra constitutional means without necessarily complying with the amendment rules set in the constitution. What is needed here is the active involvement of political parties in the process negotiation manifesting popular will. ${ }^{133}$ Thus, article 39 and other provisions of the FDRE Constitution (that are subject to unduly strict amendment rules) could be amended following this model. The active participation of political parties and the people in the amendment process could rectify the violation of amendment rules. ${ }^{134}$

Regarding the design of the amendment process, it is possible to take a lesson from the constitution making experience of South Africa. One of the most contentious issues in charting post-Apartheid South Africa was the manner of making the new constitution. Different political parties proposed different paths in accordance with their own interests. The National Party sought the adoption of a new constitution through negotiation. ${ }^{135}$ It chose

${ }^{131}$ Zelalem Eshetu Degife (2019), 'The Politics of Constitutional Amendment in Ethiopia, Issues Worth Considering, 8 Harmaya Law Review: 17-39.

132 Richard Albert (2009), 'Nonconstitutional Amendments' XXII Canadian Journal of Law and Jurisprudence, 5-47

133 Ibid

${ }^{134}$ Zelalem, supra note 132: 17.

${ }^{135}$ Hassen Ebrahim and Laurel E. Miller (2010), 'Creating the Birth Certificate of a New South Africa Constitution Making after Apartheid' in Laurel E Miller (eds) Framing the State in Times of Transition: Case Studies in Constitution Making (United States Institute of Peace) 111-148. 
this avenue because it wanted to protect the interests of the White minority. Since Black South Africans are the majority, the adoption of the constitution by an elected assembly was thought to put Whites in a disadvantageous position. The African National Congress vehemently opposed this proposal of the National Party. It contended that the adoption of the constitution by an elected constitutional assembly is the only way of ensuring the legitimacy of the constitution. ${ }^{136}$

Subsequently, the two parties made a compromise and agreed to adopt the constitution in two phases. The first phase involved the adoption of an Interim Constitution (IC) through negotiations among political parties. ${ }^{137}$ It embodied 34 key constitutional principles which the final constitution needed to comply with. The Constitutional Court of South Africa (CCSA) was mandated to check the conformity of the text of the final constitution with the general principles incorporated under the Interim Constitution. ${ }^{138}$ The second phase of the constitution making process, involved the adoption of the final constitution by an elected constitutional assembly. Unlike the IC, the members of the assembly were determined based on the performance of the parties in the election. In the assembly, members of the ANC had the upper hand. ${ }^{139}$ After considerable participation of the public at different stages of the process and the certification of its content by the CCSA, the final constitution was adopted in 1996. A similar procedure could be followed in Ethiopia to amend the FDRE constitution. Yet, the extent of polarization between political parties could pose a significant challenge.

The other venue is interpretation of the different parts of the Constitution where human dignity is expressly or impliedly stated to make it the central value of the entire constitutional order. This is a grand task as it requires a unique approach of interpretation and a great level of imagination, given the textual constraints in the present Constitution. Although this may also be reliable, it could dilute the extreme division of the nation along ethnic lines and contribute for national unity and better protection of human rights.

For this to happen, this author proposes 'purposive constitutional interpretation'. ${ }^{140}$ What distinguishes this approach from others is that it

\footnotetext{
${ }^{136}$ Ibid.

${ }^{137}$ Heinz Klug (2010), The Constitution of South Africa a Contextual Analysis, (Hart

Publishing), 23-36.

${ }^{138} \mathrm{Ibid}$.

${ }^{139}$ Ebrahim \& Miller, supra note 135, at 126-128.

${ }^{140}$ Barak, supra note 4, at 69-102.
} 
does not give too much weight for the literal meaning of the constitutional text. Its focus is rather on discovering the 'purpose' the constitutional text serves to fulfill in a 'democratic society' at the 'time of the constitutional interpretation'. ${ }^{141}$ As such, it gives priority to interpreting the constitution in light of values of a democratic society one of the most fundamental of which is respect for human dignity. It also looks forward not merely to the intent of the drafters at the time of the making, and at times, may revisit unwarranted and misinformed intent of the framers as expressed in their minutes. It tries to respond to the new circumstances and need of the society as well.

The starting point for this grand task of interpretation could be the Preamble of the Constitution, which is believed to incorporate the fundamental tenants of the existing constitutional order. The preamble states the aspiration of the NNPs of Ethiopia to establish 'a political community founded on rule of law and capable of ensuring a lasting peace, guaranteeing a democratic order, and advancing our economic and social development' ${ }^{142}$

Even though human dignity is absent from this statement, the other part of the Preamble might be helpful in this regard. It reads: 'firmly convinced that the fulfillment of this objective requires full respect of individual and people's fundamental freedoms and rights, to live together on the basis of equality and without any sexual, religious or cultural discrimination. ${ }^{143}$ Although human dignity is not expressly articulated, the reference made to individual and communal rights of equality may be interpreted as an implied acknowledgment of the importance of human dignity. Other systems have also conceived human dignity to mean the recognition of individual rights within the framework of the community based on the assumption of basic human equality. ${ }^{144}$ This seems to be the essence of human dignity in its crudest form.

Several provisions of the FDRE Constitution are also pivotal in the reconstruction of human dignity as its founding value. For example, the section outlining the fundamental principles of the Constitution embodies a provision, which affirms that 'human rights and freedoms, emanating from the nature of mankind, are inviolable and inalienable'. ${ }^{145}$ This provision is very crucial because it expressly mentions that the source of human rights is human nature which can be interpreted as an expression which includes

\footnotetext{
${ }^{141}$ Ibid

${ }^{142}$ FDRE Constitution, supra note 59, preamble.

143 Ibid.

${ }^{144}$ Kommers, supra note 43.

${ }^{145}$ FDRE Constitution, supra note 59, art 10.
} 
human dignity. Accordingly, it is possible to argue that the foundation for human rights under the FDRE Constitution is human dignity and it is an implicit founding value. Further, it is also possible to argue that human dignity is absolute and supreme value in the Constitution as it makes human rights inviolable and inalienable. ${ }^{146}$ It further means that they are intrinsic to human nature and that they must not be taken away.

It could also be argued that human dignity is not only an implied constitutional value in Ethiopia but also an expressly recognized constitutional right. ${ }^{147}$ The provision titled 'the right to honor and reputation' encompasses several constitutive elements of human dignity. The first sub article says, 'everyone has the right to respect for his human dignity, reputation and honor'. ${ }^{148}$ These phrases seem to convey different message. Otherwise, there is no reason to use different phrases for the same meaning. The term human dignity seems to connote the general respect that a human being deserves by virtue of his membership of the human family. Reputation seems to cover a specific aspect of human dignity which seeks to preserve the good name of the person. Issues such as false accusation may fall under this category. The honor part seems to cover a person's right not to be humiliated. Honor and reputation seem to focus on safeguarding the emotional component of a human person. However, this is not the whole story. The physical aspect of human dignity is also impliedly recognized in the Constitution. Everyone has the right to protection against cruel, inhuman or degrading treatment or punishment. ${ }^{149}$

More progressively, the Constitution could also be interpreted to embrace the equality and autonomy aspects of human dignity. On the issue of equality, the Constitution states that the "law shall guarantee to all persons equal and effective protection without discrimination on grounds of race, nation, nationality, or other social origin, color, sex, language, religion, political or other opinion, property, birth or other status' ${ }^{150}$ The Constitution prohibits any form of discrimination on a number of specified grounds. It has also left the list open-ended to include new grounds when the need arises. This is indeed very progressive.

\footnotetext{
${ }^{146}$ Ibid.

147 Ibid.

${ }^{148} \mathrm{Id}$. art 24.

${ }^{149} \mathrm{Id}$. art 18 .

${ }^{150} \mathrm{Id}$. art 25.
} 
With regard to the autonomy aspect of human dignity, the Constitution provides 'everyone has the right to the free development of his personality in a manner compatible with the rights of other citizens.. ${ }^{151}$ According to this provision, every human being in Ethiopia is entitled to individual selfdetermination and to chart his destiny. The only limitation is the exercise of rights of others. The provision has a striking similarity with the free development of personality clause of the German basic law, which is often used to implement the constitutional value of human dignity. ${ }^{152} \mathrm{~A}$ combined reading of these provisions suggests that human dignity could be interpreted as recognized in the FDRE Constitution both as implied value and express rights. Different components of human dignity could also be said to have constitutional ground. This enables the constitutional interpreters to give meaning to human dignity in the suggested manner and make it the organizing principle of the constitutional order.

The challenge relating to interpretation lies on whether the House of Federation is capable of discharging this task of creatively interpreting fundamental rights in the manner suggested. The framers of the FDRE Constitution have given the mandate of constitutional interpretation to the House of Federation. This was because they perceived the constitution as covenant between NNP's thereby considering constitutional interpretation by courts undemocratic as judges are unelected; and the framers mistrusted courts with the protection of group rights. ${ }^{153}$ Yet, since members of the House of Federation are not elected themselves, it is difficult to see how they meet the democratic test.

It is also hard to imagine how NNPs became the contracting parties when the Constitution was adopted. As stated in most social contract theories, the contracting parties are individual citizens not groups. ${ }^{154}$ Notably, the adequate protection of fundamental rights was not one of the main considerations when the power of constitutional interpretation was given to the House of Federation. The bias towards group rights endangers the protection of individual rights. More importantly, the organizational structure of the House of Federation cannot ensure the impartiality of the institution. According to Adem, the House of Federation is a political

${ }^{151} I d$. art 24(2).

152 Eberle, supra note 28.

153 Gossaye Ayele (2017), 'Revisiting the Justification for Vesting Constitutional Interpretation Authority in the House of Federation', 4 Ethiopian Journal of Federal Studies, 37-62.

${ }^{154}$ Ibid. 
institution having close link with other organs of the government including the executive and cannot be considered as an impartial adjudicator. ${ }^{155}$ Based on this finding, he recommends the transfer of constitutional interpretation power to courts which can serve as legitimate guardians of the Constitution and fundamental rights. If human dignity centered interpretation of constitutional rights is to take the center stage, the power of constitutional interpretation should indeed be handed over to courts. And there is no apparent reason why courts would not be trusted regarding the protection of group rights.

\section{Conclusion}

The preceding sections have examined the historical foundation of the FDRE Constitution and its design in light of promoting national unity and improving the protection of human rights. It is argued that what best characterizes the modern Ethiopian state from its very establishment to date is not the oppression of one ethnic group by another as emphasized in the design of the FDRE Constitution, but the lack of respect for human dignity. This is manifested in the failure of the state to respect the intrinsic worth of human life, physical and emotional integrity, recognition of equal worth of every person regardless of ethnicity, religion or gender, as well as lack of respect for autonomy and self-determination.

Beside its comprehensiveness, the human dignity framework also promotes solidarity and national unity among Ethiopian people, by not singling out a particular ethnic group for all the evils that happened in the hands of the past Ethiopian rulers. Moreover, respect for human dignity is all embracing since it safeguards the core interests of individuals and communities be it ethnic or religious. It could serve as a founding value or social fabric that binds all Ethiopian people together under the umbrella of democratic citizenship. Human dignity centered constitutionalism is thus the way forward for Ethiopia to ensure the adequate protection of constitutional rights as it plays a founding, interpretative and generative role.

There are two avenues of making human dignity the founding value of the constitutional order. The first is through constitutional amendment that explicitly puts human dignity as the building block of the constitutional system. This must be accompanied with some changes that potentially

155 Adem Kassie Abebe (2012), The Potential Role of Constitutional Review in the Realization of Human Rights in Ethiopia, LLD dissertation University of Pretoria, Center for Human Rights, October 2012, vi, 80-91 
strengthen national unity which includes substitution of reference to the NNPs in the preamble of the Constitution and using the words ' $W e$, the Ethiopian People', and omitting the Stalinist phrase in art 39(4), i.e. the 'right to secession' by formulating a clear statement about the unity and indivisibility of the Ethiopian nation. The right of ethnic communities to self-determination, to develop their culture and tradition will also be recognized as long as they do not impose disproportionate limitations on the rights of individuals. Instead of ethnic identity, Ethiopian citizenship should be the primary criteria for distribution of rights and privileges in the Constitution. To implement this, it is necessary to revisit the existing federal arrangement in a manner that avoids unjust discrimination, address the interests of both the majority and minority as well as balance the interest of individual and groups. This harmonizes national unity and the right of ethnic communities.

In terms of time, since Ethiopia is going through a reform, it seems to be the right time to revisit the Constitution as part of the effort to solve multifaceted problems of the nation. There also seems to be the political will to do this on the part of the ruling party as well as the opposition. Yet, the procedural hurdle set in the Constitution may render the suggested amendments impossible. To overcome this, amending the Constitution through extra constitutional means and negotiation between political parties should be considered with active participation of citizens in the process. In the meantime, creative and imaginative interpretation may be the other avenue to bring human dignity to the center of Ethiopian constitutional discourse. Yet, due to the limits imposed by the constitutional text, this task is likely to be arduous and less effective.

As a way out, this author proposes 'purposive' approach in interpretation that primarily focuses on the purpose a constitution fulfils in a 'democratic society' at the time of its interpretation rather than its adoption. This approach is preferable because it helps to transcend the intent of the framers and the literal language of the constitutional text in construing the Constitution. Through such approach, it may be possible to interpret the various provisions of the Constitution harmoniously and make human dignity a founding value and right in the Ethiopian constitutional order. Such purposive interpretation of the Constitution may at least positively contribute towards diluting extreme ethno-nationalist narratives, promoting unity among the people and enhancing protection of constitutional rights. Yet, it is difficult to imagine the realization of these objectives through creative interpretation without handing over the mandate of constitutional interpretation to courts. 